\title{
Archaeological, Alethurgical, and Dispositif Analysis: Discourse Studies on Higher Education in Poland from a Post-Foucauldian Perspective
}

\author{
Helena Ostrowicka \\ Kazimierz Wielki University, Poland
}

DOI: http://dx.doi.org/10.18778/1733-8077.17.1.8

Keywords:

Discourse Studies;

Archaeological

Discourse Analysis;

Alethurgical

Discourse Analysis;

Dispositif Discourse

Analysis; Higher

Education; Michel

Foucault

\begin{abstract}
At the present stage of the reception of Foucault's ideas, various theoretical and methodological trends coexist, within which the concepts of Michel Foucault are used fruitfully in empirical research. One of them is discourse studies understood as an inter- and transdisciplinary research area. This article distinguishes and describes three post-Foucauldian strategies of discourse analysis, the combined use of which in one research project is a proposal to integrate concepts scattered in Foucault's various works. The strategies distinguished (archaeological, alethurgical, and dispositif) are characterized by the different analytical categories, understanding of discourse, and its relations with knowledge and power. The article presents selected results of the complementary use of concepts such as knowledge formation, alethurgy, confession, or the dispositif in the empirical research on the reform of higher education in Poland.
\end{abstract}

Helena Ostrowicka is a PhD, Hab., Associate Professor, Dean of the Faculty of Pedagogy, and Head of the Department of Research Methodology and Discourse Studies at Kazimierz Wielki University in Bydgoszcz, Poland. Her research areas are: policy and educational discourse analysis, reception of Foucauldian ideas in educational research, science and higher education policy, discourses on the youth and citizenship. She is the author of five monographs (i.a., Regulating Social Life: Discourses on the Youth and the Dispositif of Age 2019, Palgrave Macmillan; co-author: The Dispositif of the University Reform. The Higher Education Policy Discourse in Poland, 2020, Routledge) and many articles published, among others, in Discourse: Studies in the Cultural Politics of Education, Educational Philosophy and Theory, Higher Education Research \& Development, European Educational Research Journal.

email address: hostrowicka@ukw.edu.pl 


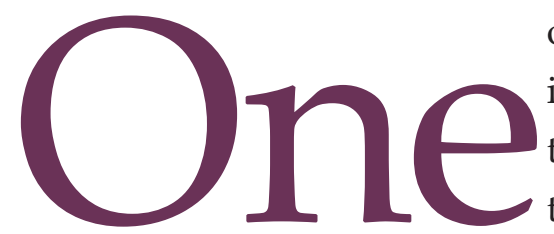

of the most inspiring and, as it has turned out over time, also one of the most frequently quoted statements by Michel Foucault (1972:21) is the question he formulated in The Archaeology of Knowledge: "How is it that one particular statement appeared rather than another?" This general question posed by Foucault and its various detailed variations formulated in subsequent lectures and publications have been provoking, for decades, the development of discourse studies, known as (post-)Foucauldian analysis. At the present stage of its development, the theoretical assumptions, and methods of research procedure in relation to specific research problems are already quite well described (e.g., Åkerstrøm Andersen 2003; Diaz-Bone 2005; Diaz-Bone et al. 2007; Angermüller and van Dyk 2010; Keller 2011; Nowicka-Franczak 2017; Ostrowicka 2017; 2019). It is also worth noting that discourse researchers, benefiting from Foucault's wealth of achievements, use a diverse range of analytical concepts and categories. However, the research is based on a discussion about the possibilities and limitations of concretizing Foucault's concepts in empirical research on current social contexts and phenomena, distant from Foucault's direct interests. The three voices distinguished by Magdalena Nowicka-Franczak (2017) can be located on a continuum from praxeological positions, through distanced voices, to skeptical ones. The supporters of the praxeological positions see in Foucault's work a "toolbox" and a kind of matrix with concepts and categories operationalized in relation to specific empirical problems. The voices from the skeptical positions express the conviction that Foucault's method cannot be repeated and applied to the study of other empirical materials, and any attempts to combine them with qualitative research methods evoke a clear resistance. In the middle of the line of this dispute there are positions that distance themselves from considering Foucault's proposal as a method in the strict sense of the term, but perceive its role as a meta-method, a specific critical attitude that distinguishes the post-Foucauldian perspective from other trends in discourse analysis (cf. also Klemm and Glasze 2005; Diaz-Bone et al. 2007). This article is an expression of the adoption of the first position, and thus recognition of not only the heuristic and meta-theoretical potential, but also the methodological usefulness of Foucault's works for contemporary empirical analyses of knowledge, power, discourse, and subjectivity. For I am close to the cognitive perspective in which concepts play the role of a method, and thus are a proposal on how to go further from a given point (cf. Tanesini 1994). It is a methodological position that assumes that theory constructs empirical cognition and that the concepts used are a specific form of thinking and, as such, can be defined and redefined in a specific way for selected purposes.

Accordingly, the purpose of this text is twofold. Firstly, on the basis of my own research experience, I want to identify and show the specificity of three analytical strategies in post-Foucauldian discourse research. I am going to show the analytical and heuristic potential of archaeologically-, alethurgically-, and dispositif-oriented analysis. Secondly, I am going to present selected results of a research project into the reform of higher education in which these strategies have been applied. I mean here the results of the research project I led in the years 2015-2019, entitled "The governmentality of university-a discursive image of the contemporary reform of higher education in Poland." This project is an example of research where different strategies are intertwined and complementary. Distinguishing them in this text 
results from the need for a methodological reflection on some of the tropes of the post-Foucauldian discourse analysis, ${ }^{1}$ the differentiated realizations of which are related to the ambiguity of Foucault's (see: 1972; 1981) concept of discourse. Although the analytical value of some terms is certainly derived from the precision of their meaning, in the case of a concept such as discourse, we owe its multi-context usefulness to the ability to stimulate ambiguity (cf. Bernard and Spencer 2010). In line with the terminology adopted by discourse scholars, the "post" perspective is referred to here because it is based on concepts and categories derived from Foucault's lectures and other works, but adapted and modified for new empirical purposes. Although in his research Foucault used materials in the form of various texts, documents, diaries, or notes, he did not conduct "discourse analyses" in the sense that is common today, that is, as a specific methodology of empirical research.

\section{Context and Aims of the Research Project}

The project, the selected results of which will serve as an exemplification of the research conducted into post-Foucauldian discourse analysis strategies, is the result of interest in the discursive mechanisms governing the transformation of the system of science ${ }^{2}$ and higher education in Poland. The years covered by the analysis (2011-2014) are the time of implementing a new and, in many assumptions, radical reform of this sector. By the Act

\footnotetext{
${ }^{1}$ And as a proposal based on my own research, this text does not cover all possible and existing tropes of post-Foucauldian analysis. Such a task would exceed the size of a standard academic article.

2 "Science" here refers to the research function in all fields of study, not only in what is understood in the English language as sciences, but also in the humanities.
}

of 2011, Barbara Kudrycka, the Minister for Science and Higher Education, ended the period of "policy of no-policy" (Kwiek 2009), that is, the years of the spontaneous drifting of higher education without much state control. In the first dozen or so years after the system transformation in 1989, Polish higher education experienced an "educational boom" and hardly limited development of non-state universities, and, as a result, problems arose related to insufficient supervision over the quality of education (Antonowicz 2015). On the other hand, in the recent decade, the core of the controversy has been the solving of the problem of the decline in the number of applicants for studies (Antonowicz and Gorlewski 2011). The reform introduced in 2011 (and its subsequent amendments), was a manifestation of the state authorities' interest in the deeper regulation and control of the system. Its preparation, and then introduction, launched a wide public debate in which, on a different scale, almost all the actors in the field of higher education were involved, that is, academic teachers, students, the ministry, entrepreneurs, and employers. And it is this debate and the discursive mechanisms of power that have led to the contemporary transformation of the university that has become the subject of our research interests.

One should begin with a reminder that discourse studies, understood as empirical research in social sciences, are based, on the one hand, on certain theoretical concepts of discourse and, on the other hand, on methodological assumptions about its analysis. Referring to the Foucauldian tradition, we understood the concept of discourse broadly as "a group of statements in so far as they belong to the same discursive formation; it does not form a rhetorical or formal unity, endlessly repeatable, whose appearance or use in history might be indi- 
cated (and, if necessary, explained); it is made up of a limited number of statements for which a group of conditions of existence can be defined" (Foucault 1972:91). Each statement introduces an entire set of rules that have formed its object, modality, the concepts used by it, and the strategy to which it belongs. In this sense: "Discourses are, therefore, about what can be said, and thought, but also about who can speak, when, where, and with what authority. Discourses embody meaning and social relations, they constitute both subjectivity and power relations" (Ball 1990:17). As Rainer Diaz-Bone, Andrea D. Bührmann, Encarnación Rodríguez Gutiérrez, Werner Schneider, Gavin Kendall, and Francisco Tirado (2007) emphasize, Foucault looked at the conditions for the emergence of discourse and the changes that took place under its influence, presenting discourse as an order which is self-sufficient and unavailable at the level of intentions of the individuals involved in it. The Foucauldian notion of discourse thus raises the question of the limits and the way in which a certain type of regime operates, which shape the modality of a statement that aspires to be true, or has the status of fiction, or is a performative act that constitutes an event in the non-discursive space (Bytniewski 2017).

Referring to Foucault's wealth of achievements, we found many analytical categories that inspired us to look at the various aspects of statements mobilized in the context of reforming the contemporary university and modeling relations on the discourse-knowledge-power-subject axis. The research perspective was based on the assumption that in Foucault's entire writing, and not only in the phases called archaeological or genealogical, one can find categories for the analysis of the principles and procedures of discourse control, selection, organization, and distribution.
The theoretical perspective adopted in our research and the scope of empirical materials made it possible to achieve two related goals. They were:

1. the reconstruction of the knowledge that the discourse on the reform produces, and that which makes it possible, and

2. the identification of legal, disciplinary, and security techniques and strategies, thanks to which the authority operates and achieves its goals.

The corpus of the analyzed materials included texts published in the years 2011-2014, thematically related to the area of science and higher education:

- scientific $^{3}$ and popular science texts published in journals devoted to higher education and science,

- press texts: the seven most opinion-forming nationwide dailies and weeklies (based on reports of the Institute of Media Monitoring, the following titles were selected: Dziennik Gazeta Prawna, Gazeta Wyborcza, Rzeczpospolita, Newsweek, Polityka, W Sieci, Wprost).

- monographs and post-conference proceedings. ${ }^{4}$

In total, the collection of empirical materials included: 884 press texts, 39 scientific articles (published in the journals Nauka, Nauka i Szkolnictwo Wyższe, and

\footnotetext{
${ }^{3}$ The starting point in the process of selecting journals was the list of ranked journals announced in 2015 by the Minister for Science and Higher Education in Poland (see: www.bip.nauka. gov.pl/, retrieved January 18, 2021).

${ }^{4}$ The body of the analyzed monographs was built on the basis of the results of a search in the database of the Polish National Library according to the subject heading "higher education."
} 
Pedagogika Szkoły Wyższej), 17 scientific books, and 319 popular science articles (from the journal Forum Akademickie $^{5}$ ).

The applied post-Foucauldian perspective did not lead to a detailed analysis of language, but aimed at recognizing the principles, techniques, and strategies which are the form and emanation of power relations mediated in discourse. We assumed that what can be said at a given historical moment in the institutional contexts of science, government, and media regulates academic life, and normalizes and naturalizes the system of higher education and science and its change in Poland in the second decade of the $21^{\text {st }}$ century.

In the following parts, I am going to sketch the post-Foucauldian analytical strategies that have been used in the project and its selected results. In distinguishing analytical strategies, I assume that at the methodological level it is possible to define the categories of analysis in which they become "pulsating tools" and can be transferred to the study of various socio-political contexts, also those distant from Foucault's immediate interests and experiences. The plane that determines their adequacy in a specific research project is always the ontological and epistemological assumptions about the subject of research and theoretical foundations of the research problem. In the case of our research, the theoretical framework was primarily the concept of governmentality, which in the social sciences has received an extremely favorable and multifaceted reception (cf. McKee 2009; Dean 2010; Bröckling, Krasmann, and Lemke 2011; McIlvenny, Zhukova Klausen, and Bang Lindegaard 2016;

\footnotetext{
${ }^{5}$ Forum Akademickie (Academic Forum) is a nationwide, widely available, monthly journal of an informative and journalistic nature, presenting key issues in the academic milieu.
}

cf. also Marek Czyżewski's text in this volume). As a perspective sensitive to subtle knowledge-power relations, the concept of governmentality has also been recognized in higher education research. On this basis, it is interpreted in two ways, that is, as a specific form of neoliberal power, based on the responsibility of individuals, security strategies, and other liberal technologies of governing the population (e.g., Simons 2006; Liesner 2007; Cannizzo 2015; Sethy 2018), and as the multiplicity and integration of different power modalities, for example, neoliberal discipline and power (Thiel 2019), or the so-called "hybrid governmentality" combining liberal democracy with socio-cultural hierarchical order (Sen 2019).

In our research, the concept of governmentality encompassed various modalities of power (independent, disciplinary, pastoral, or neoliberal), the integral elements of which (i.e., rationalities, technologies, procedures) undergo changes, semantic reconfiguration, and "recoding" in new socio-cultural and political conditions (cf. Ostrowicka 2020). In this sense, the theoretical notion of governmentality emphasizing the relationship of rationality and knowledge production processes with power has become a framework linking Foucault's ideas of discursive formations (knowledge formations), veridic (alethurgical) practices, and of the dispositif.

\section{Archaeological Discourse Analysis}

I call the first analytical strategy which is distinguished here archaeological, as it derives the basic analytical categories from the work The Archaeology of Knowledge, considered to be an interpretation of Foucault's archaeological method. The key assumptions for this perspective concern the concept of 
knowledge and the rules of its formation. Foucault used the concept of knowledge in two senses, narrow and wide-in the narrow sense, when he spoke of connaissance, that is, knowledge formalized in the form of scientific, philosophical, and religious theories and systems; in the broad sense, when he studied savoir, that is, knowledge comprising both institutionalized forms and the socio-cultural conditions of its emergence and development. It is worth recalling here that from Foucault's (1972:182183) perspective:

This group of elements, formed in a regular manner by a discursive practice, and which are indispensable to the constitution of a science, although they are not necessarily destined to give rise to one, can be called knowledge [savoir]. Knowledge is that which one can speak of in a discursive practice, and which is specified by that fact: the domain constituted by the different objects that will or will not acquire a scientific status...; knowledge is also a space in which a subject may take up a position and speak of the objects with which he deals in his discourse...; knowledge is also the field of coordination and subordination of statements in which concepts appear, and are defined, applied and transformed...; lastly, knowledge is defined by the possibilities of use and appropriation offered by discourse...; there is no knowledge without a particular discursive practice; and any discursive practice may be defined by the knowledge that it forms.

Foucault wrote about discourse as formations of knowledge, for example, in the context of clinical or psychiatric discourse. He called biology, mathematics, and economics "discourses." Therefore, archaeologically-oriented discourse analysis attaches special importance to the notion of knowledge and the rules for its formation in discursive practices. Statements construed not as speech acts, grammatical, or logical sentences, but as discursive events, are created as part of discursive practices. Statements are of interest because of the role they play in establishing a network of relations in a given discursive field (see: Bacchi and Bonham 2014). However, The Archaeology of Knowledge is not a textbook for discourse analysts, but rather a collection of notions and heuristic concepts, and a source of ideas. Some researchers, such as Antti Saari (2017), find inspiration there, more in Foucault's "reflective" style than in his "method." Foucault's concepts are linked by researchers into discourse with other theoretical traditions developed in the field of social sciences and linguistics. For example, in post-Foucauldian research focused on the concept of knowledge, additional theoretical impulses flow from sociological theories. One of the best known, especially in the German-speaking circle, is Reiner Keller's (2011) theoretical-methodological proposal of the Sociology of Knowledge Approach to Discourse, inspired by the approach to knowledge by Peter Berger and Thomas Luckmann (1966).

In general, discourse researchers referring to the archaeology of knowledge are interested in formation rules at four levels: object formation, subject position, concepts, and strategies (Åkerstrøm Andersen 2003). As Niels Åkerstrøm Andersen (2003:32) notes, "archaeology illuminates the emergence and regimental character of the discourse." In our research, we focused on the regularities of the formation of the object of discourse, that is, on the answers to questions about the surfaces of the emergence of discourse, the instances that delimit it, and the patterns that lead to the classification and specification of statements about the transformation of various aspects of higher education in Poland. 
The surfaces of the emergence of the object of discourse are places and social relations within which certain practices become the object of knowledge and the object of interest of science. The instances of delimitation, in turn, refer to authorities that have the power to distinguish, designate, and describe individuals. Questions are asked here about who (or what) defines certain phenomena as problems (e.g., social, educational, political), and who profiles and distributes knowledge. The instances are responsible for expressing the specific content and forms of knowledge, and determining its scope and distribution process. Another rule describes the constitution of the objects of discourse by placing them in the grids of specification according to which the objects are separated from each other, combined, grouped, and classified according to their selected properties (see: Foucault 1972; Ostrowicka 2019).

\section{Table 1. Analytical categories-archaeological discourse analysis}

\section{ANALYTICAL CATEGORIES}

\begin{abstract}
The surface of the emergence of the object of discourse
\end{abstract}

The grid of specification

The instance of delimitation
The space in which certain practices become the object of knowledge and the object of interest of science

A rule that serves as a criterion for differentiating and categorizing statements

An authority the function of which is to distinguish, mark, and differentiate phenomena, events, and objects
Source: Self-elaboration.

In our research into discourse, which crystallized during the implementation of Barbara Kudrycka's reform, we were interested in the formations of knowledge in the field of:

1. reforming higher education and science in Poland,

2. academic teacher-student relations,

3. evaluation of the scientific activity.

The concept of formations of knowledge assumes the epistemological importance of discourse, according to which knowledge is a space of coexistence and dependence of statements (Ostrowicka 2019). According to Foucault's definition, each statement relates to other statements creating a network of related statements: "there is no statement in general, no free, neutral, independent statement; but a statement always belongs to a series or a whole, always plays a role among other statements, deriving support from them and distinguishing itself from them: it is always part of a network of statements, in which it has a role, however minimal it may be, to play" (Foucault 1972:77). A statement triggers another and, at the same time, places itself within the relationships between them in the space of knowledge, which also includes ways of talking about the goals of governing, justifying them, creating problems, and their model solutions.

The performed analyses of academic discourse revealed that the basic surface on which the issue of reform came to the fore was the phenomenon of relativization of the university and of the direction of its transformation, covering three overlapping areas of knowledge:

- the model of the university (universitas studiorum-a manufacturing university and a $3^{\text {rd }}$ generation university), 
- higher education management (state "management center"-a local-global network of relations),

- academic culture (a culture of trust-a culture of the audit).

The academic discourse was focused on the analysis and assessment of the consequences of new legal regulations and in particular, it concerned the ideological resources of the changes and their basic actors, the mistakes made during the reform, the areas in which reform is necessary, as well as the gains and losses from the changes. The diagnosis of the status quo performed two basic functions here. On the one hand, it provided justification for the reform of the university and, on the other hand, it encouraged critical reflection on the direction of the introduced reforms. The point of contact of the discourse participants was the sense of the debate, which turned the possibility of negotiating positions into a correction mechanism and space of "keeping an eye on each other." The principle of a public debate turned out to be an instance of delimiting an object of discourse, a mechanism for legitimizing various points of view and "truths" about the reform of science and higher education. Knowledge about the reform was clearly varied. It was a space for the coordination of statements and the emergence, application, and transformation of concepts of:

- the reform as time (the past, present, and future of the university),

- the reform as space (the meeting of what is global with what is local),

- the reform as a driving force in scientific discourse,

- the reform as hope for improving the condition of science and higher education,
- the reform as a lost opportunity to improve the condition of science and higher education (see: Spychalska-Stasiak and Ostrowicka 2020).

Statements about academic relations and their contemporary changes were closely related to the concepts of the reform constructed as part of the discourse. The reconstruction of the formations of knowledge about academic teachers and students led us to the following conclusions.

Firstly, the characteristics of the research and teaching staff were located at the meeting of traditional and manufacturing university models, while statements about students emerged in the context of a reformed university, put to the test of the bureaucratic audit machine, the Bologna process directives, and the needs of the labor market. The evaluation of academic relations was conducted from both a descriptive and a normative perspective.

Secondly, the glorified figure of a true professor was confronted with the figure of a professor-a meek laborer or a hopeless teacher and scientist deprived of willingness to work. The relations constructed as part of the discourse emphasized the dissonance between professors and students, who were responsive to the expectations of modern times, emphasizing three discursive figures: a statistical student, a student-client, and a student-rebellious citizen (Spychalska-Stasiak 2019).

It is worth noting that the analyzed discourse was not always polarized. A clearly pejorative picture of the contemporary condition of academia was outlined in the discussion on changes in the evaluation of the scientific activity of an institution of science. The dispute over parameterization emerged on the 
surface of the five main threads of the discourse. They were:

1. the reform of science and higher education in Poland,

2. the environmental and media visions of science in Poland,

3. scientific journals and their citations,

4. the theoretical and methodological foundations of scientometric analyses and the results of the research carried out on their basis,

5. the practice of parametric evaluation of scientific units.

The more or less scattered or consolidated statements shared subordination to the two schemas that differentiated the object of discourse. They were: the objectives of the statement (reporting and evaluative, or persuasive) and the type of criticism undertaken. The critical tone of the analyzed statements manifested itself in two ways.

Firstly, as a certain ideal of scientific knowledge (see: Filipowicz 2012), an expression of its autonomy in the pursuit of truth, related to the necessity of constantly doubting, being inquisitive, and self-reflective. As part of this type of criticism, the concept came to the fore of parameterization as a standardized procedure for methodologically grounded and objective research, aimed, despite the errors, problems, and pitfalls listed, to generate an ordered map of science in Poland.

Secondly, we were dealing with criticism that expressed the exercise of the right to speak out on important matters, assigned to scientists. This type of critique has formed the knowledge of parameterization as a space for contention about the following issues:
- parametric evaluation accuracy and criteria,

- national uniqueness versus the globality of science, and

- the identity of the humanities versus the universalism of science.

The broadly understood academic experience, one both derived from direct involvement in conducting the evaluations and from the research experience, turned out to be an instance of legitimizing statements about parameterization. The ultimate prerogative to formulate statements was the authority derived from the positions and academic titles held, and the status of an expert confirmed by numerous awards and the recognition of the academic community (Ostrowicka and Spychalska-Stasiak 2020).

To conclude this part of the article, it is worth repeating that the post-Foucauldian perspective adopted in our research emphasized not so much the question of what is knowledge about the reform of education and science, but the problem of how this knowledge is constructed (formed). The archaeological strategy is based on challenging the idea of an autonomous and central subject of discourse. The matrix for the analysis of the formation of knowledge about higher education in Poland in the context of its reform in the years 2011-2014 consisted of three categories: the surface of the emergence of the object of discourse, the grid of specification, and the instance of delimitation of discourse. An important assumption regarding the concept of discourse has become its epistemological significance. Thus, the archaeological analysis led to an answer to the question about the formations of knowledge that make possible, consolidate, and form the reality of reformed academia. The categories of discourse analysis derived from The Archaeology of Knowledge sensitized us to the emergence 
of statements about higher education at a specific historical moment and in an institutional context (of science, government, and/or the media). During the implementation of Barbara Kudrycka's reform, we had to deal with an explosion of the discourse on the "problems" of science and academic education, unprecedented in the public space in Poland. The preparation and implementation of the Act of 2011 and the accompanying Regulations of the Minister, which introduced changes to the system, stimulated local centers of discursivization, that is, knowledge-power centers. While looking at knowledge from the archaeological perspective, we have reconstructed the rules of formation of the object of discourse, the alethurgical strategy has directed the analyses towards a certain kind of regime to which the subject of academia, placed "in the view" of the authority, is subordinated.

\section{Alethurgical Discourse Analysis}

The strategy of alethurgical analysis is oriented towards the tracking down of the so-called rituals of the manifestations of truth. They are discursive, ritualized, and regulated mechanisms that develop into relationships of power. The basic categories of analysis come from Foucault's lectures at the Collège de France, published under the title On the Government of the Living (2014). These are the categories of the alethurgy of the oracle and the alethurgy of testimony. The issue of the relationship between the subject and the truth was also developed by Foucault in his lectures in the years 1981-1982 on "the hermeneutics of the subject" (Foucault 2005). It is worth recalling at this point that Foucault, while studying medieval Christianity and Hellenistic culture, found the rituals of producing the truth that developed and transferred to the social and institutional relations present in contemporary society, for example, in the judiciary, medicine, education, or in the family (cf. also Rose 1990; Taylor 2010). The rituals of the manifestation of truth were described by him as alethurgy. Alethurgy is "the manifestations of truth as a set of possible verbal and non-verbal procedures by which one brings to light what is laid down as true as opposed to false, hidden, inexpressible, unforeseeable, or forgotten" (Foucault 2014:7). Following Foucault's lectures, we assumed that the criteria used to differentiate alethurgy types are:

- procedure of extracting the truth,

- modality of knowledge, and

- temporal orientation (see: Table 2).

The "acts of truth" are that part of the alethurgical procedures which falls to the subject. The role of the subject is threefold, that is, the subject can act as an agent (performer), thanks to whom the truth comes to light, as a spectator (witness) of the fulfillment of an act of truth, and as the actual object of alethurgy, when the truth about the subject is spoken. The purest form of the latter case is a confession, which is also an expression of the complete act of truth, in which the subject is both the performer of alethurgy, its witness, and its object (Foucault 2014). In The History of Sexuality, Foucault described how modern man has become a confessional subject. In turn, in his lectures at the Collège de France in the years 1979-1980, he included the issues of confession in the framework of research into government. It is worth emphasizing at this point that the term "government" has a comprehensive meaning, as it includes techniques and procedures for managing one's own and others' conduct: "it designated the way in which the conduct of individuals or of groups might be directed: the government of children, of souls, of communities, of families, of the sick" (Foucault 
1982:221). In the case of research into the practice of confession, it was about a specific form of government, that is, "government by the truth"-"the regime of truth" (cf. Foucault 2014).

Discourse researchers such as Brendan K. O’Rourke and Martyn Pitt (2007) highlight the "technology of the confessional" that works both in everyday social interactions and in research practice. Their research based on interview data exemplifies the combination of Foucault's insights into discourse with techniques of conversation analysis. In general, empirical research identifies contemporary confessional practices in various areas of social life, for example, in the field of therapeutic intervention, lifelong counseling, "mediated" parenting, effective learning, or educational policy (cf. Besley 2005; Fejes and Dahlstedt 2013; Fejes and Nicoll 2015). A common plane of reference is Foucault's claims about a confessional society (cf. Foucault 1978).

The "will to know" characteristic of Western societies, described by Foucault, triggered veridic rituals that became identifiable also in the academic space in numerous public statements. The analysis led to answers to questions about how the truth is revealed, to whom, and what is the subject of it. The concepts related to alethurgical strategy drew our attention to the problem of the discursive production of knowledge in relations with "the other." The "other" was not, however, identified with a psychophysical being, but with any form of audience. In alethurgical analysis, the constitutive argument of Foucault's philosophy about the omnipresence of power relations took the form of discursive practices defined as prophetic alethurgy and testimony alethurgy. They are both a tool and an effect of governing oneself and others using "truth."

\section{Table 2. Analytical categories-alethurgical discourse analysis}

\begin{tabular}{|c|c|c|c|}
\hline $\begin{array}{l}\text { Analytical } \\
\text { categories }\end{array}$ & $\begin{array}{l}\text { The } \\
\text { procedure } \\
\text { of extracting } \\
\text { the truth }\end{array}$ & $\begin{array}{l}\text { Modality of } \\
\text { knowledge }\end{array}$ & $\begin{array}{l}\text { Temporal } \\
\text { orientation }\end{array}$ \\
\hline $\begin{array}{l}\text { Divine } \\
\text { (oracle) } \\
\text { alethurgy }\end{array}$ & $\begin{array}{l}\text { Based on } \\
\text { consulta- } \\
\text { tion logic }\end{array}$ & $\begin{array}{l}\text { The truth of } \\
\text { overview in } \\
\text { the creator's } \\
\text { strength; } \\
\text { seeing, saying, } \\
\text { looking, and } \\
\text { discourse unity }\end{array}$ & $\begin{array}{l}\text { Linking the } \\
\text { present and } \\
\text { the future } \\
\text { (obligations, } \\
\text { prohibitions, } \\
\text { predictions) }\end{array}$ \\
\hline $\begin{array}{c}\text { Slave } \\
\text { (testimony) } \\
\text { alethurgy }\end{array}$ & $\begin{array}{l}\text { Based on } \\
\text { interroga- } \\
\text { tion logic }\end{array}$ & $\begin{array}{l}\text { The truth of } \\
\text { overview in } \\
\text { the witness's } \\
\text { seeing, saying, } \\
\text { and looking }\end{array}$ & $\begin{array}{l}\text { Linking } \\
\text { the present } \\
\text { and the past } \\
\text { (recollections, } \\
\text { memories, } \\
\text { confessions) }\end{array}$ \\
\hline
\end{tabular}

Source: Self-elaboration.

In our studies, using the analytical categories presented in Table 2, we analyzed the rituals of truth production in academic discourse. Statements about the reform of science and higher education were formulated both in the formula of oracle alethurgy and testimony alethurgy. In the former case, they were based on the scientific type of knowledge and methods of producing it. The temporal orientation of the analyzed discourse revealed the discursive connection of the present with the future for such purposes as:

- justification for the need for change in higher education,

- justification for a critical reflection on the ongoing changes (Spychalska-Stasiak and Ostrowicka 2020). 
On the other hand, testimony alethurgy took the form of confessions. A confession is an alethurgy in which the author of the statement is also its subject. The speaker speaks about himself or herself, about his or her experiences, emotions, actions, successes, and failures, experiences, and plans, et cetera.

We analyzed the phenomenon of academic confession taking into account the statements of professors (including the professors performing political functions) and beginner researchers (PhD students and PhDs) published in the popular science monthly Forum Akademickie. The analysis of the statements they formulated revealed differences in the object and form of the confession, as well as the instances that launched the "discourses of truth" of these three, and not other entities (Ostrowicka and Spychalska-Stasiak 2018).

The professors' statements shared the specific rhetoric of "a man with experience," and their confessions were built as part of the reflection on their own biography and the reasons for the decisions made by them in their lives in the context of systemic changes, university changes, and academic work conditions. Stories about their own research careers were often emotional and self-critical.

The statements of academics who, apart from their scientific role, also indicated their political commitment, were particularly demanding in terms of interpretation. The discourse of academics-politicians was subordinated to a specific strategy of functionalization, resulting in a clear embedding of confession in the context of professional activity. Emotional descriptions of experiences and individually shaped understanding were replaced here by distanced statements of a witness participating in the management of science and higher education.
In turn, the top-down control of both the subject matter and the form of a statement was a special feature of the confessions of the so-called beginner researchers. The confessions of doctoral students and doctors were subordinated to the convention adopted by the editorial office. This group includes the statements of:

1. laureates of the competition organized by the publisher of Forum Akademickie under the title "Complicated and simple. Young Academics about Their Research"; the form of the laureates' statements had to be adjusted in order to conform to the established regulations,

2. young lecturers, who addressed short, several-sentence letters to the expert appearing in the journal, hoping to be helped in solving the teaching dilemmas experienced; their form had to be in line with the convention of the column called "Our expert advises," devised by the editorial office,

3. participants in the "Top 500 Innovators" program organized by the Ministry of Science and Higher Education, who during the interview presented their reflections on their stay at Stanford University.

The confessions of young academics were, therefore, focused on the characteristics of the method of conducting research, the experience gained on their basis, and on the good and bad sides of research and teaching work, as well as on the specificity of the Polish academic milieu.

The journal Forum Akademickie was also a space for the formation of a discourse on the parameterization and evaluation of the academic activity. In this case, we were dealing with the mutual reference of 
the alethurgy of testimony with the alethurgy of the oracle. The latter was considered significant when it was based on experience. Participants in the discourse on parametrization played different roles, that is, those of:

- performers-evaluators, thanks to whom a certain "truth" about Polish academia was revealed,

- witnesses of the fulfillment of the act of truth in the evaluation procedure,

- the subjects of alethurgy, since the truth about them, their academic position, and identity was told (Ostrowicka and Spychalska-Stasiak 2020).

In other words, the truth was manifested, if the "prophet" who presented visions of the future of the university was at the same time a "witness" experiencing parameterization.

Selecting for our analyses categories relating to veridic practices, we linked discourse analysis with the concept of alethurgy, which directed the research towards procedures of extracting the truth, the modalities of knowledge, and temporal orientations in the discourse on the reform of higher education in Poland. Confession as an analytical category in discourse research led to the concentration of the analysis on selected aspects, that is, the author, subject, and form of the statement, and encouragement to speak, that is, whom/what (what instance) demands confession. The basis of the applied alethurgical strategy was interest in the relationships between the rituals of manifesting the truth about academia and the mechanisms of government. Studying alethurgical practices, we discovered the "regime" of governing oneself and others through "acts of truth," that is, discursive practices in which the subject of academia referred to some truth as part of the alethurgy of the witness or the alethurgy of the prophet. The alethurgical strategy of analysis makes it possible to extract, in the general phenomenon of the discursivization of academic work, those elements which situate discourse participants in relation to the truth.

\section{Dispositif Discourse Analysis}

The dispositif strategy in discourse analysis derives its assumptions from several works by Foucault, in which he described, and genealogically analyzed, the different variants of the mechanisms of disciplinary, juridical, and neoliberal power (cf. Foucault 1977; 1978; 2008; 2009). The dispositif as a theoretical and analytical category in discourse research includes in its scope of interest those factors that are sometimes referred to as extra-discursive. I mean here, first of all, the organizational and material elements of social reality. However, at the root of Foucault's concept of the dispositif is an attempt to abandon the opposition between what is discursive and non-discursive, and the basic message becomes the functionality of a specific set or system (ensemble) of discursive and non-discursive elements as a mechanism of power (Foucault et al. 1994).

The most extensive definition of the dispositif was presented by Foucault in 1977 in an interview for the magazine Ornicar?, emphasizing its strategic role in neutralizing and explaining sudden and non-routine situations (Nowicka 2016). But, it is in the lectures at the Collège de France in the years 1977-1979 (Foucault 2009) that we find analyses of the various modalities of the dispositif (i.e., juridical, disciplinary, and security dispositifs) and their functions. Staying close to Foucault's concept, in the dispositif strategy of discourse analysis we focused on the study of the various modalities of the dis- 
positif, aiming at the reconstruction of governmentality processes. Owing to the significance of the concept of discourse in the research on the dispositif, the applied strategy can be considered a variant of the so-called dispositif analysis. This trend in the reception of Foucault's ideas has significantly developed in recent years (e.g., Bührmann and Schneider 2008; Truschkat 2008; Wengler, Hoffarth, and Kumięga 2013; Ostrowicka 2019; Nowicka-Franczak in this volume).

\section{Table 3. Analytical categories-dispositif discourse analysis}

\begin{tabular}{|c|c|c|c|c|}
\hline $\begin{array}{c}\text { Analytical } \\
\text { categories }\end{array}$ & Normative order & $\begin{array}{c}\text { Techniques of } \\
\text { power }\end{array}$ & Fields of visibility \\
objectifications
\end{tabular}

Source: Self-elaboration.

In the dispositif strategy of discourse analysis, "the dispositif" is a theoretical concept and, therefore, contains some general statements about the prototype modalities of power. The individual analytical categories (i.e., normative order, techniques of power, fields of visibility, objectification of the subject) used in the conducted research on the governmentality of the university have been listed in Table 3. The juridical, disciplinary, and security dispositifs have been classified in the categories of prototype mechanisms, the contemporary transformations of which can be reconstructed using discourse analysis (Raffnsøe, Gudmand-Høyer, and Thaning 2014). The dispositif strategy was not a closed set of concepts, but expressed preferences in terms of the categories of the analysis of power in its various forms. The research was aimed at thematically and functionally identifying discourses related to science and academic education, as well as the mechanisms of 
law, discipline, and security co-operating in the reforming of the university.

The conducted research has shown that a network of knowledge-power relations, absorbing knowledge about the population of students and academic teachers and introducing interventions at the threefold levels of individuals, groups, and institutions, was created in the system of higher education in Poland which was subjected to change. In academic discourse, a responsiblized, entrepreneurial university is also a repressed university.

The change in the evaluation of academic activity, which introduced quantitative indicators for the assessment of the productivity and quality of academic work, intensified a discourse of two kinds. On the one hand, the statements of academics expressed the reaction of the academic community to the core of the introduced modifications, while, on the other hand, they became an expression of (re)defining the subjectivities constituting the social order of the university. Thus, along with the broadly understood criticism of parameterization, three types of subjectivity and the rationalities characteristic of them were revealed, that is, defensive, adaptive, and entrepreneurial (Ostrowicka and Spychalska-Stasiak 2020).

In the case of students whose position and status change with the change of the university model, we could see their progressive economic functionalization. The discourses of international organizations such as the European Union, the European Higher Education Area (created under the Bologna Process), and the Organization for Economic Cooperation and Development, played a major role in determining the goals of the student population and the techniques to be used to help them imple- ment these goals. Adopting their perspective made it possible for the Ministry to define higher education and students mainly by relating them to the knowledge-based economy to be created and to the current needs of the labor market. The conceptualization of students as a "product," and previously as "material," made it possible for the government to assign specific roles to the individual actors in the field of higher education, that is, to universities, the government, employers, and students. These roles were distributed as follows:

1. the task of higher education is to satisfy employers' needs for a qualified workforce and to create a human capital base;

2. the government's tasks include the transferring of information between the labor market and high school graduates in order to make the choices of the latter rational, that is, in line with the needs of employers, forecasting economic changes, and ensuring the legal framework and adequate financing for education;

3. the task of universities is to adjust educational programs to the needs of the economy and employers, indicated by the government, among other things by including the latter in the planning of teaching work;

4. the task of employers is to inform about their needs and, possibly, to cooperate with universities to establish educational programs that are favorable to them;

5. the only task of high school graduates is to rationally match their educational choices to the signals from the government, labor market, and universities. 
The implementation of thus conceptualized goals required the use of a number of techniques. The following mechanisms have been introduced to combine the disciplining, hierarchization, and control of students with neoliberal regulations at the system level:

- information mechanisms making it possible to coordinate activities between the different actors of higher education;

- mechanisms used by the Ministry to directly affect the provision of the supply of educational courses;

- mechanisms to differentiate and hierarchize universities (Stankiewicz and Ostrowicka 2020a).

Mass education has become a debated issue for the media, the university, and for government representatives. The dominant discourse promoted the pattern of higher education as an elite good, in which the presence of the masses posed a constant threat to society and its development. One of the solutions for the threat emerging in various areas has become the progressive juridification of the system (Stankiewicz and Ostrowicka 2020b). The more and more advanced tools for collecting information were accompanied by the proliferation of legal regulations, while "amending" them on a permanent basis forced attention, constant translation of regulations, and adaptation. The changes in the law carried out from 2011 to 2014 resulted in the achievement of a few objectives:

1. creating a system of competition between institutions of science (within the public and non-public school sector) and between employees, both in the area of science and education,

2. contractualization and formalization of relations between entities of the higher education system (including the relations between higher education institutions and students),

3. limiting the opportunities for cronyism or nepotism in the academic community by introducing a system of bureaucratic control,

4. putting higher education institutions within the area of influence of external entities, that is, the state and entrepreneurs (Stankiewicz and Ostrowicka 2020b).

It is worth noting here that such deep mechanisms of competition within the higher education system were a new phenomenon in the Polish situation, contributing to the polarization of public debate (Dziedziczak-Foltyn 2017; Stankiewicz and Ostrowicka 2020b).

Our research has shown that the contemporary subject of academia has become not only the object of systematic observation, but is also itself motivated to observe in order to be well informed. In the new cultural context, old, proven technologies of power have created new hybrid networks of relations, integrating potentially conflicting and competing discourses. The culturally grounded assumption about the cause-effect relations between the school and the labor market (learning outcomes and vocational preparation) has brought together the main participants in the debate (university students/graduates and their employees, employers, and entrepreneurs) and have become the basis for the construction of the discourse on universities as "factories of the unemployed" (Ostrowicka and Stankiewicz 2019), and also made it possible to undermine the value of education in the field of the humanities and to develop the syndrome of "the crisis of the humanities." Humanists, along with entrepreneurs, were the most 
active group speaking in the press. Their voices expressed primarily dissatisfaction with the direction of the reforms. In general, analyses of the methods of the academic problematization of the reform showed that for the so-called ordinary academics, not directly involved in the implementation of the proposed changes, it is an external and foreign creation. This position "towards" the reform and the exogenous nature of regulations made it possible for academics to develop a rationalizing framework for reacting to the changes, that is, their acceptance, opposition, resistance, passivity, or indifference. The resistance to the reform, when it was connected with attempts to formulate a positive project of academic identity, was based on ethical discourse and recalling the ideal Humboldtian type (see: Chomik and Ostrowicka 2019; Falkowski and Ostrowicka 2020).

Summing up, the dispositif analytical strategy revealed the coexistence and interaction of the mechanisms of law, discipline, and security in the efficient governance and reform of higher education in Poland. Statements formulated in a media or academic context understood as carriers of power and as an integral element of disciplining, juridification, and securitization techniques have been analyzed through the prism of normative orders, power techniques, fields of visibility, and objectification of subjects. In the general phenomenon of discursivization of the problems of higher education, the concept of dispositif in discourse analysis brought out the multidimensionality of power relations and the usefulness of various types of knowledge, the interpenetration of strategies of managing an individual and population, codification, normalization, and other regulatory practices. The way of connecting various heterogeneous techniques of power or normative orders and their contemporary implementations have shown the specificity of the discourse constructed in a specific historical and socio-political context. I hope that the combination of dispositif analysis with archaeological and alethurgical analysis in one research project has made it possible for us to capture the ambiguous, theoretical concept of discourse in its various empirical versions while remaining in line with the post-Foucauldian perspective.

\section{Discussion and Concluding Remarks}

Undoubtedly, the development of post-Foucauldian discourse analysis belongs to an important stream of qualitative social research. We can follow the process of constituting this research perspective in the context of other methodological trends, drawing to a different extent and for a different purpose from Foucault's work. The process of reception on the basis of methodology is visible in, among others, textbooks for social research. For example, in well-known works edited by Norman K. Denzin and Yvonna S. Lincoln, there are two chapters entirely devoted to the interpretation of Foucault's methodology (see: Holstein and Gubrium 2005; Scheurich and McKenzie 2008). On the other hand, the books by David Silverman $(2001$; 2005) provide many examples of the involvement of Foucault's thought in specific research projects, but they do not devote any space to the description or explanation of the concepts characteristic of this philosopher. Overall, these and other social research methodology textbooks prove that Foucault's concepts appear on three levels in research projects. First, as an epistemological frame overriding categories derived from other approaches (e.g., phenomenography, frame analysis, conversational analysis, grounded theory, narrative research). This is how Foucault's concepts of discourse or "the politics of truth" often function. Secondly, as analytical tools subordinated to the research goals formulated in the framework of "non-Foucauld- 
ian" theoretical trends. This is what happened with, among others, the categories of the panopticon and disciplinary power that are used in research based on the "non-Foucauldian" version of critical theory (cf. Scheurich and McKenzie 2008). Third, and finally, Foucault's ideas and concepts are used as categories equal and complementary to others, such as in the proposal by James A. Holstein and Jaber F. Gubrium (2005) linking Foucault's concepts with ethnomethodology or, in my earlier research, integrating Foucault's concept of dispositif with Reinhart Koselleck's historical semantics (cf. Ostrowicka 2019).

In terms of the methodology of discourse analysis, at least two tendencies are visible. On the one hand, Foucault's approaches to discourse are considered to be the basis for creating new, comprehensive, and independent theoretical and methodological concepts, such as Critical Discourse Analysis, Argumentative Discourse Analysis, Discursive Institutionalism, or the Sociology of Knowledge Approach to Discourse (see: Leipold and Winkel 2013). On the other hand, discourse researchers emphasize the specificity of the post-Foucauldian perspective, recognizing that it is more than just a loose inspiration from Foucault's conceptualism, and looking for common points for the so-called research perspective. It is worth adding that this task is not facilitated by the growing number of discursive studies (see: Angermuller, Maingueneau, and Wodak 2014). There are discussions about whether there is one methodology for post-Foucauldian discourse research, and if so, what constitutes its assumptions, basic strategies, and tools (cf. Diaz-Bone et al. 2007). Two decades ago, Johannes Angermüller (2001) distinguished two trends in post-Foucauldian research, that is, pragmatic, micro-sociological analys es, and post-structural, related to linguists' interest in ideological analyses. Over time, the state of reception has become more diversified within specific disciplines and in interdisciplinary research, and as a result of the development of discourse studies as a research field aspiring to take up transdisciplinary problems.

The issue of the development of post-Foucauldian methodology is also part of a more general dilemma, which can be expressed by the question: are we not contradicting the Foucauldian principle of the author's transgression by formulating rules of discourse analysis that would be consistent with Foucault's methodology? Foucault's writing gives us an aporia that is difficult to overcome, the creative potential of which lies in the possibility of transgressing the state of "current" or "obligatory" interpretations. Certainly, there are already important and valuable proposals for the methodology of post-Foucauldian analysis, only a fragment of which was noted by me in the earlier parts of the article. However, thinking similarly to Bernadette Baker (2007) and Antti Saari (2017), I believe it would be highly problematic for the post-Foucauldian perspective to become a monolith that inhibits the generation of new approaches to discourse research. Saari (2017:102) is right when he writes: "If Foucault's works are to be relevant in the future, they must be kept from solidifying too much into methodological checklists and rigid concepts." The analytical strategies described in this article are an expression of our experimenting with concepts scattered in various works by Foucault and trying to integrate them into one research project. The identification of three strategies is an ex post activity, that is, a secondary reflection on the set of analytical categories used. For I am close to the conviction that at the stage of analyzing research materials, a rigid separation of the three stages (and methods) in Foucault's writing is unnecessary, because, in research practice, they often combine and complement one another. Based on the example of the research proj- 
ect led by me, I have tried to show the possibility of complementary use of three different, but related and complementary, analytical strategies that emphasize the ambiguity of the concept of discourse and its relationship with the categories of knowledge and power. In this integrative approach, I see the value of the synthetic form of the methodological proposal described here. Its weakness is certainly the fact that it is the result of choice and selection from many other possible combinations.

In my opinion, however, discourse studies, like any other theoretical and methodological trend, are activities that reduce complex social reality. As Ludwik Fleck (1986:122-123 [trans. HO]) aptly noted years ago, "it is altogether pointless to speak of all the characteristics of a structure. The number of characteristics can be as large as desired, and the number of possible determinations of characteristics depends upon the habits of thought of the given scientific discipline." Post-Foucauldian strategies are an expression of a directed perception of those elements of reality which, as part of a certain community of thought (or a "thought collective," as Fleck would say), are seen as important. It has been known for a long time that Foucault did not provide a systematic interpretation of his method, and he used many of the concepts important to him in various functions and meanings. However, this did not hamper discourse researchers; on the contrary, it inspired them to transfer Foucault's ideas to new territories, absent in the philosopher's oeuvre. This was also the case, for example, in the field of research on higher education (cf. Sousa and Magalhaes 2013; Ostrowicka 2018; Angermuller et al. 2019).

In this article, I have described in a synthetic form the theoretical and analytical categories, which have become important in the research project I am managing on the discourse launched in connection with the reform of higher education in Poland in the years 2011-2014. The large-scale research objectives, encompassing discourses constructed in three institutional contexts (those of science, the government, and the media), were based on the notions and ideas of Foucault, but were not limited exclusively to them. ${ }^{6}$ Preferences in terms of specific categories have led me to distinguish and use three analytical strategies, that is, archaeological, alethurgical, and dispositif. Assuming a certain level of generality, it may be concluded that these strategies are characterized by the different placement of accents in the analysis and understanding of discourse. In the archaeological strategy, discourse becomes a synonym of knowledge. The researcher is interested in its formations (of knowledge) in discursive practices. In alethurgical analysis, the focus is additionally on the speaking subject and the mechanisms in which knowledge is manifested as truth. Here, discourse becomes, in the Foucauldian sense, the "regime of truth." On the other hand, the dispositif strategy aims at the reconstruction of specific relations on the knowledge-power-subject axis in the form of discipline, law, and the security dispositif. In this case, discourse is seen as a certain semiotic "order" of diversified power mechanisms.

The use of different analytical strategies in one research project was, in our case, like a trek across uneven terrain, starting from multiple points to capture the landscape of higher education reform both in the near and far perspectives.

\section{Acknowledgements}

This work was supported by the National Science Center in Poland under grant number 2014/14/E/HS6/00671.

\footnotetext{
${ }^{6}$ Important sources of inspiration were also the theory of public debate and crisis by Bob Jessop $(2002 ; 2008)$ and Waldemar Czachur's (2011) concept of the discursive image of the world.
} 


\section{References}

Angermüller, Johannes. 2001. “Diskursanalyse: Strömungen, Tendenzen, Perspektiven. Eine Einführung [Discourse Analysis: Currents, Tendencies, Perspectives. An Introduction]." Pp. 7-22 in Diskursanalyse: Theorien, Methoden, Anwendungen [Discourse Analysis: Theories, Methods, Applications], edited by J. Angermüller, K. Bunzmann, and M. Nonhoff. Hamburg: Argument.

Angermüller, Johannes and Silke van Dyk. 2010. Diskursanalyse meets Gouvernementalitätsforschung. Perspektiven auf das Verhältnis von Subjekt, Sprache, Macht und Wissen [Discourse Analysis Meets Governmentality Research. Perspectives on the Relationship between Subject, Language, Power, and Knowledge]. Frankfurt, New York: Campus.

Angermuller, Johannes, Dominique Maingueneau, and Ruth Wodak, eds. 2014. The Discourse Studies Reader. Main Currents in Theory and Analysis. Amsterdam, Philadelphia: John Benjamins Publishing Company.

Angermuller, Johannes et al. 2019. "The Academic Dispositif: Towards a Context-Centred Discourse Analysis." Pp. 51-87 in Quantifying Approaches to Discourse for Social Scientists, edited by R. Scholz. London: Palgrave Macmillan.

Antonowicz, Dominik. 2015. Między siła globalnych procesów a lokalna tradycja. Polskie szkolnictwo wyższe w dobie przemian [Between Global Processes and Local Tradition: Higher Education in Poland in the Times of Change]. Torun: UMK.

Antonowicz, Dominik and Bartłomiej Gorlewski. 2011. Demograficzne tsunami. Raport Instytutu Sokratesa na temat wptywu zmian demograficznych na szkolnictwo wyższe do 2020 roku [The Demographic Tsunami. The Socrates Institute Report on the Impact of Demographic Change on Higher Education until 2020]. Warsaw: Instytut Sokratesa.

Åkerstrøm Andersen, Niels. 2003. Discursive Analytical Strategies. Understanding Foucault, Koselleck, Laclau, Luhmann. Glasgow: The Policy Press.

Bacchi, Carol and Jennifer Bonham. 2014. "Reclaiming Discursive Practices as an Analytic Focus: Political Implications." Foucault Studies 17:173-192.

Baker, Bernadette. 2007. "Normalizing Foucault? A Rhizomatic Approach to Plateaus in Anglophone Educational Research." Foucault Studies 4:78-119.
Ball, Stephen J. 1990. Politics and Policy Making in Education: Explorations in Policy Sociology. London: Routledge.

Berger, Peter and Thomas Luckmann. 1966. The Social Construction of Society. New York: Doubleday.

Bernard, Alan and Jonathan Spencer, eds. 2010. The Routledge Encyclopedia of Social and Cultural Anthropology. Second Edition. New York, London: Routledge.

Besley, Tina A. C. 2005. “Self-Denial or Self-Mastery? Foucault's Genealogy of the Confessional Self." British Journal of Guidance $\mathcal{E}$ Counselling 33(3):365-382.

Bröckling, Urlich, Susanne Krasmann, and Thomas Lemke, eds. 2011. Governmentality: Current Issues and Future Challenges. New York: Routledge.

Bührmann, Andrea D. and Werner Schneider. 2008. Vom Diskurs zum Dispositiv: Eine Einführung in die Dispositivanalyse [From Discourse to Dispositive: An Introduction to Dispositive Analysis]. Bielefeld: Transcript.

Bytniewski, Paweł. 2017. "Foucaulta pojęcie dyskursu - ryzyko użycia [Foucault's Concept of Discourse-The Risk of Use]." Roczniki Historii Socjologii VII:57-71.

Cannizzo, Fabian. 2015. “Academic Subjectivities: Governmentality and Self-Development in Higher Education." Foucault Studies 20:199-217.

Chomik, Dominik and Helena Ostrowicka. 2019. “The Status Quo, Imponderables of Change, and Evaluation: Between Higher Education Policy and Academic Discourse." Forum Qualitative Sozialforschung / Forum: Qualitative Social Research 20(1): Art. 11.

Czachur, Waldemar. 2011. “Dyskursywny obraz świata. Kilka refleksji [The Discursive Image of the World. A Few Reflections]." Tekst i Dyskurs 4:79-97.

Dean, Mitchel. 2010. Governmentality: Power and Rule in Modern Society. London: Sage.

Diaz-Bone, Rainer. 2005. "Zur Methodologisierung der Foucaultschen Diskursanalyse [On the Methodology of Foucault's Discourse Analysis]." Forum Qualitative Sozialforschung / Forum: Qualitative Social Research 7(1): Art. 6. 
Diaz-Bone, Rainer et al. 2007. "The Field of Foucauldian Discourse Analysis: Structures, Developments and Perspectives." Forum Qualitative Sozialforschung / Forum: Qualitative Social Research 8(2): Art. 30.

Dziedziczak-Foltyn, Agnieszka. 2017. Reforma szkolnictwa wyższego w Polsce w debacie publicznej [The Reform of Higher Education in Poland in the Public Debate]. Lodz: Wydawnictwo UŁ.

Falkowski, Tomasz and Helena Ostrowicka. 2020. "Ethicalisation of Higher Education Reform: The Strategic Integration of Academic Discourse on Scholarly Ethos." Educational Philosophy and Theory. Retrieved January 18, 2021 (https://doi.org/10.10 80/00131857.2020.1740684).

Fejes, Andreas and Magnus Dahlstedt. 2013. The Confessing Society: Foucault, Confession and Practices of Lifelong Learning. London, New York: Routledge.

Fejes, Andreas and Katherine Nicoll, eds. 2015. Foucault and a Politics of Confession in Education. London: Routledge.

Filipowicz, Stanisław. 2012. "Krytyka. Imponderabilia i strategia. [Criticism. Imponderabilia and Strategy]." Nauka (2):33-42.

Fleck, Ludwik. 1986. Powstanie i rozwój faktu naukowego. Wprowadzenie do nauki o stylu i kolektywie myślowym [The Emergence and Development of a Scientific Fact. An Introduction to Research into Style and Thought Collective]. Lublin: UMCS.

Foucault, Michel. 1972. The Archaeology of Knowledge. London: Routledge.

Foucault, Michel. 1977. Discipline and Punish. The Birth of the Prison. New York: Random House.

Foucault, Michel. 1978. The History of Sexuality. New York: Pantheon Books.

Foucault, Michel. 1981. “The Order of Discourse.” Pp. 51-78 in Untying the Text: A Post-Structuralist Reader, edited by R. Young. Boston, London, Henley: Routledge \& Kegan Paul.

Foucault, Michel. 1982. “The Subject and Power.” Pp. 208-228 in Michel Foucault: Beyond Structuralism and Hermeneutics, $2^{\text {nd }} \mathrm{ed}$., edited by H. L. Dreyfus and P. Rabinow. Chicago: University of Chicago Press.

Foucault, Michel. 2005. The Hermeneutics of the Subject: Lectures at the Collège de France 1981-1982. Reprint Edition. New York: Picador.
Foucault, Michel. 2008. The Birth of Biopolitics: Lectures at the Collège de France, 1978-1979 (A. I. Davidson, ed.). Basingstoke: Palgrave Macmillan.

Foucault, Michel. 2009. Security, Territory, Population: Lectures at the Collège de France, 1977-1978 (A. I. Davidson, ed.). New York: Palgrave Macmillan.

Foucault, Michel. 2014. On the Government of the Living. Lectures at the Collège de France, 1979-1980 (A. I. Davidson, ed.). London: Palgrave Macmillan.

Foucault, Michel et al. 1994. "Le jeu de Michel Foucault [Michel Foucault's Game]." Pp. 298-329 in M. Foucault Dits et écris III [Words and Writings III]. Paris: Gallimard.

Holstein, James A. and Jaber F. Gubrium. 2005. "Interpretive Practice and Social Action." Pp. 483-505 in Handbook of Qualitative Research, edited by N. K. Denzin and Y. S. Lincoln. Thousand Oaks, CA: Sage.

Jessop, Bob. 2002. The Future of the Capitalist State. Cambridge: Polity Press.

Jessop, Bob. 2008. “Kulturowa ekonomia polityczna a analiza dyskursu [Cultural Political Economy and Discourse Analysis]." Pp. 121-148 in Krytyczna Analiza Dyskursu. Interdyscyplinarne podejście do komunikacji społecznej [Critical Discourse Analysis: Interdisciplinary Approach to Social Communication], edited by A. Duszak and N. Faircloug. Cracow: Universitas.

Keller, Rainer. 2011. Wissenssoziologische Diskursanalyse: Grundlegung eines Forschungsprogramms [The Sociology of Knowledge Discourse Analysis: Laying the Foundations for a Research Program]. Wiesbaden: VS-Verlag.

Klemm, Jana and Georg Glasze. 2005. "Methodische Probleme Foucault-inspirierter Diskursanalysen in den Sozialwissenschaften [Methodological Problems of Foucault-Inspired Discourse Analyses in the Social Sciences]." Forum Qualitative Sozialforschung / Forum: Qualitative Social Research 6(2): Art. 24.

Kwiek, Marek. 2009. “The Two Decades of Privatization in Polish Higher Education. Cost-Sharing, Equity, and Access." Pp. 149168 in Financing Access and Equity in Higher Education, edited by J. Knight. Rotterdam, Boston, Taipei: Sense Publishers.

Leipold, Sina and Georg Winkel. 2013. "Discursive Agency: Towards an Actor-Centered Analysis of Political Discourses." Paper presented at the $1^{\text {st }}$ International Conference on Public Policy (ICPP 2013). Grenoble, France. 
Liesner, Andrea. 2007. "Governmentality, European Politics and the Neo-Liberal Reconstruction of German Universities." Policy Futures in Education 5(4):449-459.

McIlvenny, Paul, Julia Zhukova Klausen, and Laura Bang Lindegaard, eds. 2016. Studies of Discourse and Governmentality: New Perspectives and Methods. Amsterdam, Philadelphia: John Benjamins Publishing Company.

McKee, Kim. 2009. "Post-Foucauldian Governmentality: What Does It Offer Critical Social Policy Analysis?" Critical Social Policy 29(3):465-486.

Nowicka, Magdalena. 2016. “O użyteczności kategorii dyspozytywu w badaniach społecznych [On the Usefulness of the Category of Dispositif in Social Research]." Przeglad Socjologii Jakościowej 12(1):170-191.

Nowicka-Franczak, Magdalena. 2017. "Postfoucauldian Analysis of the Discourse on Education. Workshop Remarks." Culture - Society - Education 2(12):171-198.

O’Rourke, Brendan K. and Martyn Pitt. 2007. “Using the Technology of the Confessional as an Analytical Resource: Four Analytical Stances Towards Research Interviews in Discourse Analysis." Forum Qualitative Sozialforschung / Forum: Qualitative Social Research 8(2): Art. 3.

Ostrowicka, Helena. 2017. “The Educational Discourse, Veredictions and Pedagogies-From the Constellations of the Relations between Discourse and Education to the Alethurgic Analysis of the Educational Practice." Culture - Society - Education 2(12):124-142.

Ostrowicka, Helena, ed. 2018. Analiza dyskursu w badaniach szkolnictwa wyższego [Discourse Analysis in Higher Education Research]. Warsaw: Academic Publishing House SEDNO.

Ostrowicka, Helena. 2019. Regulating Social Life: Discourses on the Youth and the Dispositif of Age. Cham: Palgrave Macmillan.

Ostrowicka, Helena. 2020. "Economization of Discourse on Education and Pedagogization of Economic Problems: Media Debate on Higher Education Reform in Poland." Discourse: Studies in the Cultural Politics of Education. Retrieved January 18, 2021 (https://www.tandfonline.com/doi/ abs/10.1080/01596306.2020.1811957?journalCode=cdis20).

Ostrowicka, Helena and Justyna Spychalska-Stasiak. 2018. "Disciplining the Disciplined? 'Culture of Confession' in Academic Discourse in Poland.” Filosofija. Sociologija 4(29):314-326.
Ostrowicka, Helena and Justyna Spychalska-Stasiak. 2020. "The Responsibilized University. The Power of Parametrization." Pp. 89-114 in The Dispositif of the University Reform. The Higher Education Policy Discourse in Poland by H. Ostrowicka, J. Spychalska-Stasiak, and Ł. Stankiewicz. London, New York: Routledge.

Ostrowicka, Helena and Łukasz Stankiewicz. 2019. "The Truths of Business and the Lies of Academia: The Order of Discourse on Higher Education in Poland." Higher Education Research \& Development 38(3):609-622.

Raffnsøe, Sverre, Marius S. Gudmand-Høyer, and Morten S. Thaning. 2014. "Foucault's Dispositive: The Perspicacity of Dispositive Analytics in Organizational Research." Organization 23(2):272-298.

Rose, Nikolas. 1990. Governing the Soul: The Shaping of the Private Self. London, New York: Routledge.

Saari, Antti. 2017. “Wandering along the Moebius Strip: Radical Reflexivity in the Archaeology of Educational Research." Culture - Society - Education 2(12):129-151.

Scheurich, James J. and Kathryn B. McKenzie. 2008. “Foucault's Methodologies: Archaeology and Genealogy." Pp. 841869 in Collecting and Interpreting Qualitative Materials, edited by N. K. Denzin and Y. S. Lincoln. Thousand Oaks, CA: Sage.

Sen, Vicheth. 2019. “Hybrid Governmentality: Higher Education Policymaking in Post-Conflict Cambodia." Studies in Higher Education 44(3):513-525.

Sethy, Satya S., ed. 2018. Higher Education and Professional Ethics: Roles and Responsibilities of Teachers. New York: Routledge.

Silverman, David. 2001. Interpreting Qualitative Data. Methods for Analyzing Talk, Text and Interaction. London, Thousand Oaks, New Delhi: Sage Publications.

Silverman, David. 2005. Doing Qualitative Research. London, Thousand Oaks, New Delhi: Sage Publications.

Simons, Marten. 2006. “Learning as Investment: Notes on Governmentality and Biopolitics." Educational Philosophy and Theory 38(4):523-540.

Sousa, Sofia B. and Antonio Magalhaes. 2013. “Discourse Analysis in Higher Education Research." Pp. 81-96 in Theory and Method in Higher Education Research, edited by J. Huisman and M. Tight. Bingley: Emerald Group Publishing Limited. 
Spychalska-Stasiak, Justyna. 2019. “Universitas studiorum? Analiza formacji wiedzy na temat relacji nauczyciel akademicki - student [Universitas studiorum? An Analysis of the Formation of Knowledge about the Academic Teacher-Student Relationship]." Pp. 109-127 in Dyskursywny obraz reform szkolnictwa wyższego w Polsce 2011-2014 [The Discursive Image of the Reform of Higher Education in Poland 2011-2014] by H. Ostrowicka et al. Warsaw: Wydawnictwo Naukowe PWN.

Spychalska-Stasiak, Justyna and Helena Ostrowicka. 2020. "Academic Discourse: Formations of Knowledge about the Reform." Pp. 24-58 in The Dispositif of the University Reform. Higher Education Policy Discourse in Poland by H. Ostrowicka, J. Spychalska-Stasiak, and Ł. Stankiewicz. London, New York: Routledge.

Stankiewicz, Łukasz and Helena Ostrowicka. 2020a. "The Dispositif of Discipline and the Neoliberal Governance of Students." Pp. 114-148 in The Dispositif of the University Reform. Higher Education Policy Discourse in Poland by H. Ostrowicka, J. Spychalska-Stasiak, and Ł. Stankiewicz. London, New York: Routledge.

Stankiewicz, Łukasz and Helena Ostrowicka. 2020b. “The Dispositif of Law: The Juridification of the Higher Education System in Poland." Pp. 59-88 in The Dispositif of the University
Reform. Higher Education Policy Discourse in Poland by H. Ostrowicka, J. Spychalska-Stasiak, and Ł. Stankiewicz. London, New York: Routledge.

Tanesini, Alessandra. 1994. “Whose Language?” Pp. 203-216 in Knowing the Difference: Feminist Perspectives in Epistemology, edited by K. Lennon and M. Whitford. New York: Routledge.

Taylor, Dianna, ed. 2010. Michel Foucault. Key Concepts. London, New York: Routledge.

Thiel, Jonas. 2019. "The UK National Student Survey: An Amalgam of Discipline and Neo-Liberal Governmentality." British Educational Research Journal 45(3):538-553.

Truschkat, Inga. 2008. Kompetenzdiskurs und Bewerbungsgespräche. Eine Dispositivanalyse (neuer) Rationalitäten sozialer Differenzierung [Competence Discourse and Job Interviews. A Dispositive Analysis of (New) Rationalities of Social Differentiation]. Wiesbaden: Springer VS.

Wengler, Joannah C., Britta Hoffarth, and Łukasz Kumięga, eds. 2013. Verortungen des Dispositiv-Begriffs. Analytische Einsätze zu Raum, Bildung, Politik [Locations of the Dispositive Concept. Analytical Assignments to Space, Education, Politics]. Wiesbaden: Springer VS.

\section{Citation}

Ostrowicka, Helena. 2021. "Archaeological, Alethurgical, and Dispositif Analysis: Discourse Studies on Higher Education in Poland from a Post-Foucauldian Perspective." Qualitative Sociology Review 17(1):110-132. Retrieved Month, Year (http://www. qualitativesociologyreview.org/ENG/archive_eng.php). DOI: http://dx.doi.org/10.18778/1733-8077.17.1.8 